\title{
POLA PENGGUNAAN TELEVISI UNTUK PEMENUHAN KEBUTUHAN INFORMASI DAN PENINGKATAN KETERAMPILAN BAGI PETERNAK SAPI POTONG DI BOJONEGORO
}

\section{(The Pattern of Television Usage to Fulfill Information's Needs and Improve Skills for Cattle Farmers in Bojonegoro)}

\author{
Gian Hendra ${ }^{1}$, Amiruddin Saleh ${ }^{2}$, Retno Sri Hartati Mulyandari ${ }^{3}$ \\ ${ }^{1}$ Jurnalis Green TV IPB, Jl Lingkar Akademik Kampus IPB Dramaga \\ ${ }^{2}$ Dosen Program Studi Komunikasi Pembangunan Pertanian dan Pedesaan SPs IPB \\ ${ }^{3}$ Kepala Bidang Kerjasama dan PHP Balai Besar Pengkajian dan Pengembangan Teknologi \\ Pertanian \\ e-mail: gianhendraipb@gmail.com \\ Naskah diterima: 7 Juni 2016; Direvisi: 15 Juni 2016; Disetujui: 29 Juni 2016
}

\begin{abstract}
Breeding beef cattle is one of the agriculture sector which is very important in Indonesia. In fact the household consumption of beef can't be fulfilled by the production in the country. The attention to the human resources which are cattle ranchers have a vital role in the form of increasing knowledges and skills to advance the production of beef cattle. Television is one of a mass media that has potential to increase farmers' knowledges like cultivation knowledge and marketing knowledge in Ngantru Village, Bojonegoro District, East Java Province. The purpose of this research are 1) to analyze the characteristics, motives and patterns of breeder cattle in watching television, 2) to analyze the relation between the motifs and patterns of breeder cattle watching television with the information needs of breeding beef cattle, 3) to analyze the relation between farmers beef cattle in watching the television with the fulfillment of information needs of beef cattle breeding, and 4) to analyze the relation between the information needs of farmers skills in beef breeding. This study was designed as a survey research, with a quantitative approach supported by qualitative data with the number of respondents which are 50 people selected randomly. Analyzed using descriptive statistics and inferential statistical with Chi-Square analysis test and Spearman Rank test. The results of this research is there is a real connection between the level's of ownership of livestock with a duration of watching television. The entertainment motif has related with beef cattle farmers' pattern in watching television, like the frequency and duration. The frequency of beef cattle farmers in watching television also related with the entertainment needs.

Keywords: cattle breeding, information needs, motif, scheme, television
\end{abstract}

\section{PENDAHULUAN}

Salah satu jenis usaha peternakan saat ini yang sedang mengalami kenaikan setiap tahun adalah sapi potong. Data Badan Pusat Statistik (BPS) pada tahun 2013 mencatat produksi daging ternak sapi potong sebesar 545.621 ton daging sapi, data tersebut mengalami kenaikan dibanding data tahun 2012 yang tercatat produksi daging ternak sapi sebesar 509.905 ton (BPS 2014), kenaikan jumlah produksi ini ternyata tidak mempengaruhi pemerintah untuk tetap mengimport daging sapi potong untuk memenuhi kebutuhan masyarakat akan konsumsi daging sapi potong. Pemerintah harus memperhatikan salah satu dari subsektor pertanian tersebut supaya dapat menutupi kebutuhan konsumsi daging sapi nasional. Kebijakan pemerintah dalam subsektor peternakan mengenai peternakan sapi potong untuk menjadikan sebagai salah satu usaha yang perlu dikembangkan adalah usaha peternakan rakyat. Peternakan sapi potong merupakan salah satu bagian penting dalam perekonomian masyarakat desa di Indonesia dan sebagian merupakan usaha ternak rakyat dengan skala usaha satu sampai empat ekor per rumah tangga peternak (Wibowo \& Haryadi 2006).

Tingginya permintaan daging sapi potong harus membuat peternak untuk meningkatkan kuantitas dan kualitas 
ISSN 1693-3699

daging sapi supaya tidak kalah dengan daging import. Peningkatan kompetensi peternak diyakini perlu ditingkatkan untuk menghadapi kondisi saat ini. Kompetensi adalah kecakapan yang memadai dalam melakukan suatu tugas atau memiliki keterampilan yang diisyaratkan.

Kompetensi tersebut dapat dicapai jika peternak memiliki kemampuan dalam mengkombinasikan pengetahuan, sikap, keterampilan, dan manajerial (Yusuf 2010). Peningkatan kualitas peternak juga harus seiring dengan peningkatan pengetahuan dan kompetensi peternak. Batoa (2007) menjelaskan jika pengetahuan adalah aspek yang berhubungan dengan kemampuan mengingat materi yang telah dipelajari dan kemampuannya dalam mengembangkan intelegensia. Melihat kemajuan televisi sangatlah cepat, hingga kini bermunculan televisi swasta secara nasional maupun lokal. Kehadiran stasiun televisi terutama stasiun televisi swasta yang hadir untuk memenuhi kebutuhan informasi masyarakat. Lahirnya Undangundang No. 32 Tahun 2002 tentang penyiaran yang menjelaskan perlu dibentuknya sebuah sistem penyiaran yang menjamin terciptanya tatanan informasi nasional yang adil, merata dan seimbang.

Menurut Rakhmat (2007)

pendekatan Uses and Gratification memperlihatkan bahwa orang secara aktif mencari media dan isi tertentu untuk memperoleh kepuasan dari penggunaan media tersebut. Jahi (1998) juga menjelaskan jika media massa dapat menyediakan informasi pada khalayak dan memotivasinya untuk mengadopsi inovasi pertanian, maupun lebih tahu tentang berita nasional dan internasional. Media massa mungkin saja menimbulkan efek langsung atau tidak langsung pada perilaku khalayak pedesaan. Studi tentang khalayak (audience) televisi merupakan hal yang penting bagi penyelenggara televisi atau pembuat program guna mengetahui sejauh mana program acara yang dibuat dapat memenuhi kebutuhan dan kepuasan khalayaknya. Menurut hasil penelitian
Juli 2016 Vol 14, No 2

Rosalita (2014), banyaknya kehadiran stasiun televisi swasta menimbulkan persaingan dalam menayangkan program acara yang dapat menarik perhatian masyarakat sebagai konsumen media. Namun, program acara yang ditayangkan banyak yang kurang memberikan kontribusi positif bagi masyarakat.

Penelitian Saleh (2006) juga menjelaskan jika peternak lebih banyak terdedah oleh media radio, televisi dan surat kabar/koran akan tetapi tidak sejalan dengan kepemilikan media para peternak. Dalam penelitiannya dijelaskan jika peternak lebih banyak memiliki radio dan terdedah oleh siaran radio dibandingkan dengan televisi maupun surat kabar lainnya.

Tujuan penelitian ini adalah 1) menganalisis karakteristik, motif, dan pola peternak sapi potong dalam menonton acara televisi, 2) menganalisis hubungan antara motif dan pola peternak sapi potong menonton acara televisi dengan kebutuhan informasi beternak sapi potong, 3) menganalisis hubungan pola peternak sapi potong dalam menonton acara televisi dengan pemenuhan kebutuhan informasi beternak sapi potong, dan 4) menganalisis hubungan kebutuhan informasi dengan peningkatan keterampilan peternak sapi potong dalam beternak sapi potong.

\section{KERANGKA BERPIKIR DAN HIPOTESIS}

Sebagai media massa komunikasi, khalayak memanfaatkan televisi sebagai saluran komunikasi yang mereflesikan kebutuhan masyarakat yang tergambar dalam empat dimensi motif menonton televisi. Motif tersebut merupakan cerminan kondisi sosial masyarakat yang berharap televisi dapat berguna sebagai media informasi, pendidikan, hubungan sosial dan hiburan yang sehat dan positif bagi masyarakat secara umum. Pola menonton yang tinggi juga menunjukkan kebutuhan khalayak terhadap televisi ini. Keberadaan media massa memiliki 
manfaat yang dapat dirasakan oleh khalayak seperti, meningkatknya akses informasi meningkatkan kebutuhan hiburan.

Adanya motif dan pola tersebut untuk mewujudkan kebutuhan informasi peternakan bagi peternak. Tingkat kebutuhan informasi peternak dalam menonton televisi dapat dilihat bagaimana dalam menonton dapat terpenuhi kebutuhannya akan informasi, begitu juga dengan kebutuhan hiburan. Kebutuhan khalayak menonton televisi juga tergantung pada masing-masing individu karena memiliki karakteristik yang berbeda-beda.

Motif tersebut mendorong peternak untuk menggunakan televisi, yang penggunaannya dapat dilihat dari dua peubah, yaitu frekuensi dan durasi.

Dari beberapa komponen dalam peubah penggunaan televisi, dapat dilihat tingkat pemenuhan kebutuhan informasi bagi peternak. Kerangka pemikiran hubungan penggunaan televisi oleh peternak dengan tingkat pemenuhan kebutuhan informasi peternak dan peningkatan keterampilan peternak dapat dilihat pada Gambar 1.

\begin{tabular}{|c|c|c|}
\hline $\begin{array}{l}\text { Karakteristik Individu } \\
\text { (X1) }\end{array}$ & & $\begin{array}{l}\text { Pemenuhan } \\
\text { Kebutuhan Informasi } \\
\text { (Y2) }\end{array}$ \\
\hline $\begin{array}{ll}\text { (X1.1) } & \text { Usia } \\
(\mathrm{X} 1.2) & \text { Jenis Kelamin } \\
(\mathrm{X} 1.3) & \text { Pendidikan }\end{array}$ & & $\begin{array}{ll}\text { (Y2.1) } & \text { Budidaya } \\
\text { (Y2.2) } & \text { Pemasaran }\end{array}$ \\
\hline $\begin{array}{ll}\text { (X1.4) } & \text { Kepemilikan } \\
& \text { Ternak Sapi } \\
\text { (X1.4) } & \text { Kepemilikan }\end{array}$ & $\begin{array}{l}\text { Pola Menonton televisi } \\
\text { (Y1) }\end{array}$ & \\
\hline Medıa Massa & (Y1.1) Frekuensi & $\downarrow$ \\
\hline $\begin{array}{l}\text { Motif Menonton TV } \\
\text { (X2) }\end{array}$ & (Y1.2) Durasi & $\begin{array}{l}\text { Tingkat Keterampilan } \\
\text { (Y3) }\end{array}$ \\
\hline $\begin{array}{l}\text { (X2.1) Informasi } \\
\text { (X2.2) Hiburan }\end{array}$ & & $\begin{array}{ll}\text { (Y3.1) } & \text { Budidaya } \\
\text { (Y3.2) } & \text { Pemasaran }\end{array}$ \\
\hline
\end{tabular}

Gambar 1 Kerangka berpikir penelitian pola penggunaan televisi dalam penenuhan kebutuhan informasi dan peningkatan keterampilan peternak

Berdasarkan kerangka pemikiran tersebut, hipotesis penelitian ini yaitu 1) terdapat hubungan nyata antara karakteristik peternak sapi potong dengan pola menonton televisi, 2) terdapat hubungan nyata antara motif dengan pola menonton televisi, 3) terdapat hubungan nyata antara pola menonton dengan pemenuhan kebutuhan informasi peternakan, dan 4) terdapat hubungan nyata antara pemenuhan kebutuhan informasi dengan peningkatan keterampilan peternak sapi potong.

\section{METODE PENELITIAN}

Lokasi penelitian di Desa Ngantru, Kecamatan Kasiman, Kabupaten Bojonegoro. Waktu penelitian dimulai pada bulan Januari 2015. Penelitian didesain sebagai penelitian survei, dengan pendekatan kuantitatif didukung data kualitatif. Jumlah responden 50 orang, dipilih secara acak (simple random sampling) sesuai dengan karakteristik yang dibutuhkan penelitian, yaitu peternak sapi 
ISSN 1693-3699

potong. Analisis data menggunakan analisis statistik deskriptif, dan inferensial dengan uji chi-square dan rank Spearman menggunakan SPSS versi 16.

\section{HASIL DAN PEMBAHASAN}

\section{Karakteristik Peternak Sapi Potong}

Karakteristik peternak sapi potong yang diamati penelitian ini berupa usia, jenis kelamin, pendidikan, tingkat kepemilikan ternak sapi dan tingkat kepemilikan media.

Tabel 1 menunjukkan responden dalam penelitian ini berusia dewasa muda sebesar 14 persen, dewasa pertengahan $52 \%$, dan dewasa tua sekitar 34 persen. Melihat dari hasil pesentase tersebut, kategori dewasa pertengahan memiliki persentase terbesar dibanding dewasa muda dan dewasa tua. sehingga secara psikologis peternak yang berada pada kelompok usia dewasa muda dan dewasa pertengahan memiliki kelebihan relatif senang mencoba cara-cara baru dan dapat belajar dalam menguasai teknologi serta mampu mempertahankan retensi belajar dalam jumlah besar baik secara sendirisendiri maupun berkelompok dan memiliki sikap cepat mengadopsi suatu inovasi.

Tabel 1 Distribusi responden menurut karakteristik peternak

$$
\mathrm{n}=50
$$

Pada Tabel 1 dijelaskan peternak laki-laki lebih banyak dibanding dengan peternak wanita. Sebagian besar peternak didominasi laki-laki sebanyak 80 persen atau 40 orang dari jumlah sampel yang dipilih. Dari hasil pengamatan di lapangan, peternak laki-laki lebih jarang menonton televisi dibandingkan peternak perempuan, ini dikarenakan kegiatan mereka seharihari sebagai peternak lebih menggunakan waktunya untuk mengurus ternak dari pagi sampai sore hari.

Pendidikan yang dimaksud dalam penelitian ini adalah pendidikan yang ditempuh oleh para peternak yang dinyatakan dengan tingkat pendidikan. Ketegori pendidikan yang ditempuh oleh peternak dikategorikan menjadi tiga
Juli 2016 Vol 14, No 2

kategori mulai dari tidak lulus SD (sekolah dasar), lulus SD (sekolah dasar), dan lulus SMP (sekolah menegah pertama). Peternak yang tidak lulus SD dan lulus SMP memiliki persentase yang rendah dibandingkan dengan peternak yang pendidikannya hanya sampai lulus SD sebesar 90 persen. Persentase peternak yang tidak lulus SD sebesar 8\% atau berjumlah empat orang, persentase untuk peternak yang lulus SMP sebesar 2\% atau berjumlah satu orang. Rendahnya tingkat pendidikan para peternak disebabkan karena ada pemikiran tidak pentingnya sekolah tinggi bila pada akhirnya mereka hanya menjadi peternak seperti orang tuanya. Fasilitas sekolah lanjutan sangat minim di Desa Ngantru, akses untuk mencapai sekolah tersebut memiliki jarak tempuh yang jauh berkisar lima sampai sepuluh kilometer.

Kepemilikan ternak sapi yang dimaksud di sini adalah jumlah kepemilikan hewan ternak berupa sapi yang dimiliki oleh satu orang peternak. Kategori kepemilikan ternak sapi dikategorikan menjadi dua yaitu rendah tinggi, kategori rendah memiliki jumlah ternak sapi 1-5 ekor, kategori tinggi memiliki jumlah ternak sapi 5-10 ekor.

\begin{tabular}{lcc}
\hline $\begin{array}{l}\text { Karakteristik } \\
\text { Peternak }\end{array}$ & $\begin{array}{c}\text { Jumlah } \\
\text { (orang) }\end{array}$ & $\begin{array}{c}\text { Persentase } \\
(\%)\end{array}$ \\
\hline Usia & & \\
Dewasa Muda & 7 & 14 \\
DewasaPertengahan & 26 & 52 \\
Dewasa Tua & 17 & 34 \\
Jenis Kelamin & & \\
Laki-laki & 40 & 80 \\
Perempuan & 10 & 20 \\
Tingkat Pendidikan & & \\
Tidak Lulus SD & 4 & 8 \\
Lulus Sd & 45 & 90 \\
Lulus SMP & 1 & 2 \\
Kepemilikan Ternak & & \\
Sapi & & \\
Rendah & 43 & 86 \\
Tinggi & 7 & 14 \\
Kepemilikan Media & & \\
Rendah & 41 & 82 \\
Tinggi & 9 & 18 \\
\hline
\end{tabular}


Bedasarkan kategori tersebut, kategori rendah memiliki persentase tertinggi dibanding kategori tinggi yaitu sebesar 86 persen, kategori tinggi dengan persentase 14 persen. Tingginya persentase peternak pada kategori rendah untuk kepemilikan ternak sapi menunjukan bahwa hampir setiap kepala rumah tangga minimal memiliki satu ternak sapi.

Kategori kepemilikan media massa peternak dalam penelitian ini dikategorikan menjadi dua, rendah dan tinggi, kategori rendah hanya memiliki satu media massa, untuk kategori tinggi lebih dari satu media massa. Berdasarkan kategori tersebut, kategori rendah memiliki persentase tertinggi sebesar 82 persen dan kategori kepemilikan media tinggi memiliki persentase terendah sebesar 18 persen. Tinggi persentase pada kategori rendah ini memperlihatkan jika kebanyak dari peternak hanya memiliki satu buah media yaitu televisi. Peternak yang memiliki lebih dari satu media massa berupa televisi dan radio, untuk surat kabar tidak ada satupun peternak yang berlangganan atau memiliki. Akses yang sulit membuat surat kabar baik nasional maupun lokal sangat sulit masuk ke Desa Ngantru.

\section{Motif Menonton Televisi}

Motif khalayak menonton televisi dijabarkan sesuai dengan tipologi kebutuhan yakni: information (kebutuhan akan informasi dari lingkungan sekitar), personal identity (kebutuhan untuk menonjolkan sesuatu yang penting dalam kehidupan seseorang), integration and social interaction (dorongan untuk menggunakan media dalam rangka melanggengkan hubungan dengan individu lain) dan entertainment (kebutuhan untuk melepaskan diri dari ketegangan dan menghibur diri). Adapun motif yang dimiliki oleh peternak sapi potong dalam menonton siaran acara di televisi yang diteliti dalam penelitian ini adalah motif informasi dan hiburan, hal tersebut dapat dilihat pada Tabel 2 .

Tabel 2 Jumlah peternak sapi potong menurut motif menonton televisi

\begin{tabular}{llcc}
\hline $\begin{array}{l}\text { Motif } \\
\text { Menonton }\end{array}$ & Kategori & $\begin{array}{c}\text { Jumlah } \\
\text { (orang) }\end{array}$ & $\begin{array}{c}\text { Persentase } \\
(\%)\end{array}$ \\
\hline Informasi & Rendah & 13 & 26 \\
& Tinggi & 37 & 74 \\
Hiburan & Rendah & 28 & 56 \\
& Tinggi & 22 & 44 \\
\hline $\mathrm{n}=50$ & & &
\end{tabular}

Tabel 2 menunjukkan bahwa sebagian besar peternak menonton acara televisi adalah karena adanya kebutuhan untuk memperoleh informasi, yaitu sebesar 74 persen yang tergolong motif mencari informasi pada kategori tinggi. Tingginya dorongan motif untuk memperoleh informasi karena berbagai alasan di antaranya adalah ingin mendapatkan informasi seputar pertanian, peternakan dan pemberdayaan masyarakat yang sebelumnya tidak diketahui.

Sedangkan sebesar 56 persen memiliki motif hiburan dalam menonton televisi yang rendah. Responden lebih memilih untuk beristirahat ketimbang untuk menonton acara televisi sehabis pulang dari melakukan kegiatan beternak atau kegiatan mengambil rumput di sawah.

\section{Pola Menonton Televisi}

Dua hal yang dijadikan alat ukur untuk melihat pola khalayak menonton yakni tingkat kekerapan khalayak menonton dalam seminggu atau frekuensi, dan total waktu rata-rata atau banyaknya waktu (jam) yang dicurahkan khalayak dalam menonton televisi dalam jumlah waktu atau durasi, hal ini terlihat pada Tabel 3.

Tabel 3 Jumlah dan persentase peternak sapi potong menurut pola menonton televisi

\begin{tabular}{lccc}
\hline $\begin{array}{l}\text { Pola } \\
\text { Menonton }\end{array}$ & Kategori & $\begin{array}{c}\text { Jumlah } \\
\text { (orang) }\end{array}$ & $\begin{array}{c}\text { Persentase } \\
(\%)\end{array}$ \\
\hline Frekuensi & Rendah & 18 & 36 \\
\hline
\end{tabular}


ISSN 1693-3699

\begin{tabular}{cccc}
\hline \multirow{3}{*}{ Durasi } & Tinggi & 32 & 64 \\
& Rendah & 41 & 82 \\
& Tinggi & 9 & 18 \\
\hline
\end{tabular}

Tabel 3 menunjukan frekuensi menonton televisi adalah intensitas atau tingkat keseringan responden dalam menyaksikan acara televisi dalam satu minggu. Frekuensi menonton yang termasuk dalam kategorikan tinggi (tujuh kali dalam seminggu atau setiap hari) dalam menonton televisi adalah sebanyak 64 persen atau 32 orang. Peternak minimal dalam satu hari melakukan aktivitas menonton satu kali siaran acara televisi baik waktu pagi, siang atau malam hari.

Durasi menonton televisi adalah lamanya waktu yang digunakan oleh responden dalam menyaksikan acara televisi perhari. Durasi responden yang menonton televisi dan termasuk dalam kategori rendah adalah sebesar 82 persen atau 41 orang. Durasi menonton televisi yang rendah disebabkan karena responden memiliki kegiatan lainnya yang dilakukan atau kesibukan lainnya.

\section{Pemenuhan Kebutuhan Informasi}

Pemenuhan kebutuhan akan informasi dalam penelitian ini merupakan hasil dari penggunaan media massa berupa televisi yang diperoleh oleh peternak. Khalayak menonton televisi memiliki motif untuk pemenuhan akan kebutuhan informasi dan hiburan, hal ini dipaparkan pada Tabel 4.

Kategori pemenuhan kebutuhan informasi dibagi menjadi dua (tinggi dan rendah), akan terlihat pada Tabel 4 bahwa sebanyak 72 persen reponden yang tingkat pemenuhan informasinya melalui televisi tergolong rendah, sementara 28 persen responden yang tingkat pemenuhan informasinya melalui televisi tergolong tinggi.
Juli 2016 Vol 14, No 2

Tabel 4 Jumlah dan persentase peternak sapi potong menurut pemenuhan kebutuhan menonton televisi

\begin{tabular}{llcc}
\hline $\begin{array}{c}\text { Pemenuhan } \\
\text { Kebutuhan }\end{array}$ & Kategori & $\begin{array}{c}\text { Jumlah } \\
\text { (orang) }\end{array}$ & $\begin{array}{c}\text { Persentase } \\
(\%)\end{array}$ \\
\hline Informasi & Rendah & 36 & 72 \\
& Tinggi & 14 & 28 \\
Hiburan & Rendah & 14 & 28 \\
& Tinggi & 36 & 72 \\
\hline $\mathrm{n}=50$ & & &
\end{tabular}

Kondisi ini menggambarkan bahwa tayangan televisi saat ini lebih membuat acara hiburan dibanding acara informatif untuk memenuhi kebutuhan informasi yang dibutuhkan oleh peternak.

Kategori pemenuhan kebutuhan hiburan dibagi menjadi dua (tinggi dan rendah), akan terlihat pada Tabel 4 bahwa sebanyak 72 persen reponden yang tingkat pemenuhan kebutuhan hiburannya melalui televisi tergolong tinggi, sementara 28 persen responden yang tingkat pemenuhan kebutuhan hiburannya melalui televisi tergolong rendah.

\section{Keterampilan Peternak}

Kompetensi peternak sapi di Dusun Ngantru ini pada tingkat keterampilan peternak dengan melihat faktor-faktor yang berhubungan seperti pemilihan bibit, perkandangan pemberian pakan, penanganan kesehatan, perkawinan ternak dan pengelolaan hasil ternak yang dibagi ke dalam dua kategori yaitu rendah dan tinggi. Hasil perhitungan deskriptif dari kompetensi peternak sapi di Desa Ngantru disajikan pada Tabel 5. 
Tabel 5 Jumlah dan persentase keterampilan peternak sapi potong

\begin{tabular}{llcc}
\hline $\begin{array}{l}\text { Keterampila } \\
\mathbf{n}\end{array}$ & $\begin{array}{l}\text { Kategor } \\
\mathbf{i}\end{array}$ & $\begin{array}{c}\text { Jumla } \\
\mathbf{h} \\
\text { (orang) }\end{array}$ & $\begin{array}{c}\text { 'ersentase } \\
(\%)\end{array}$ \\
\hline Bibit & Rendah & 17 & 34 \\
& Tinggi & 33 & 66 \\
Kandang & Rendah & 41 & 82 \\
& Tinggi & 9 & 18 \\
Pakan & Rendah & 27 & 54 \\
& Tinggi & 23 & 46 \\
Kesehatan & Rendah & 28 & 56 \\
& Tinggi & 22 & 44 \\
Perkawinan & Rendah & 37 & 74 \\
& Tinggi & 13 & 26 \\
Pemasaran & Rendah & 39 & 78 \\
& Tinggi & 11 & 22 \\
\hline $\mathrm{n}=50$ & & &
\end{tabular}

Kategori dalam kompetensi

keterampilan peternak dalam penanganan bibit sapi dibagi ke dalam dua kategori yaitu rendah dan tinggi. Persentase tertinggi dalam kompetensi ini adalah pada kategori tinggi dengan persentase sebesar 66 persen, sedangkan pada kategori rendah memiliki persentase sebesar 34 persen. Tingginya persentase pada kategori sedang disebabkan karena rata-rata para peternak dapat memilih bibit sapi yang baik, dan dapat menangani bibit sapi namun sebagian besar masih kesulitan dalam mencari mendapatkan bibit sapi yang baik.

Persentase tertinggi pada kompetensi keterampilan penanganan kandang ternak sapi yaitu pada kategori rendah dengan persentase sebesar $82 \%$, sedangkan pada persentase kategori tinggi sebesar 18 persen. Tingginya persentase pada kategori rendah disebabkan oleh banyaknya peternak yang tidak bisa membuat kandang yang baik dengan syarat dan tipe yang telah ditentukan.

Persentase tertinggi pada kompetensi keterampilan penanganan pakan ternak sapi yaitu pada kategori rendah dengan persentase sebesar 54 persen, sedangkan untuk kategori tinggi memiliki persentase sebesar 46 persen. Rendahnya kompetensi peternak dalam penanganan pakan ternak dilihat dari banyaknya peternak di Desa Ngantru memiliki kompetensi yang rendah terhadap pengelolaan pakan ternak sapi mereka hal itu terlihat cara pemberian pakan yang dilakukan oleh peternak tidak banyak variasi.

Persentase tertinggi pada frekuensi kompetensi keterampilan penanganan ternak sapi terdapat pada kategori rendah dengan persentase 56 persen, sedangkan untuk kategori tinggi memiliki persentase 44 persen. Tingginya persentase pada kategori rendah dikarenakan banyaknya peternak yang tidak mengetahui keterampilan yang berkaitan dengan penanganan kesehatan ternaknya seperti mendeteksi penyakit, ciri-ciri penyakit pada sapi ternaknya, obat untuk ternak yang sakit, cara pengobatan jika ternak sakit, dan cara mencegah agar ternak tidak mengalami sakit.

Pada kompetensi keterampilan penanganan perkawinan ternak persentase pada kategori rendah sama yaitu sebesar 74 persen sedangkan pada kategori tinggi memiliki persentase sebesar 26 persen. Rendahnya persentase pada kategori tinggi dikarenakan peternak tak memiliki keterampilan dalam penangangan perkawinan ternak sapi. Hal ini dapat dilihat dengan banyaknya peternak yang meminta bantuan petugas kesehatan hewan untuk penanganan birahi hewan ternaknya, mendeteksi kebuntingan dan menangani ternak sapi yang bunting.

Dalam kompetensi keterampilan penanganan pemasaran ternak sapi potong pada peternak dibagi ke dalam dua kategori yaitu rendah dan tinggi. Dari kedua kategori yang ada kategori rendah memiliki persentase sebesar 78 persen dan kategori rendah memiliki persentase terendah sebesar 22 persen. Tingginya persentase pada kategori rendah dapat dilihat dengan keterampilan peternakan dalam hal penanganan pemasaran ternak sapi. Dimana kebanyakan dari peternak tidak memiliki keterampilan untuk memasarkan ternaknya sendiri namun 
ISSN 1693-3699

dibantu oleh pihak lain. Sedangkan untuk pengolahan hasil seperti pembuatan pupuk kandang kebanyakan dari peternak tidak memiliki keterampilan untuk mengolahnya dengan campuran bahan kimia lainnya. Peternak tidak banyak mengolah hasil ternaknya khususnya kotoran ternak. Peternak yang berada di Desa Ngantru beranggapan kotoran ternak yang ditabur di halaman hingga kering sudah dikatakan pupuk kandang.

\section{Hubungan Karakteristik dengan Pola Menonton TV Peternak Sapi Potong}

Dalam penelitian ini, karakteristik individu meliputi lima dimensi yakni: usia, jenis kelamin, pendidikan, tingkat kepemilikan ternak dan tingkat kepemilikan media massa. Bagaimana hubungan karakteristik individu dengan frekuensi menonton dan durasi menonton, dapat dilihat pada Tabel 6 .

Tabel 6 Nilai hubungan karakteristik peternak sapi potong dengan pola menonton televisi

\begin{tabular}{|c|c|c|}
\hline \multirow[t]{2}{*}{$\begin{array}{l}\text { Karakteristik } \\
\text { Peternak }\end{array}$} & \multicolumn{2}{|c|}{$\begin{array}{l}\text { Koefisien Korelasi dengan } \\
\text { Pola Menonton }\end{array}$} \\
\hline & Frekuensi & Durasi \\
\hline Usia $\left(r_{\mathrm{s}}\right)$ & 0.102 & -0.094 \\
\hline Jenis Kelamin $\left(\chi^{2}\right)$ & 0.034 & 0.087 \\
\hline Pendidikan $\left(r_{\mathrm{s}}\right)$ & -0.014 & -0.076 \\
\hline Kepemilikan & 0.062 & $0.411 * *$ \\
\hline Ternak $\left(r_{\mathrm{s}}\right)$ & & \\
\hline
\end{tabular}

Tabel 6 memperlihatkan hasil uji korelasi rank Spearman dan chi-square antara usia, jenis kelamin, pendidikan dan kepemilikan ternak. Diantara karakteristik peternak sapi potong hanya kepemilikan ternak berhubungan dengan dengan durasi peternak sapi potong dalam menonton televisi. Ini dibuktikan dengan nilai korelasi 0.411dimana nilai $\mathrm{p}$-value $\leq 0.01$, artinya jumlah ternak yang dimiliki peternak berkorelasi sangat nyata dengan pola menonton televisi peternak dalam durasi menonton. Jumlah ternak yang lebih banyak membuat para peternak
Juli 2016 Vol 14, No 2

mengeluarkan tenaga yang lebih banyak dibanding dengan peternak yang memiliki ternak sedikit sekitar satu sampai tiga ternak sapi, karena itu peternak yang memiliki hewan ternak sedikit memiliki durasi menonton tv yang lebih besar dibandingkan peternak yang memiliki jumlah ternak yang banyak. Usia, jenis kelamin, pendidikan tidak memiliki perbedaan dalam pola menonton peternak sapi potong.

\section{Hubungan Motif Menonton dengan Pola Menonton TV Peternak Sapi Potong}

Hubungan motif menonton dengan pola menonton dapat dilihat pada Tabel 7 .

Tabel 7 Nilai hubungan motif menonton peternak sapi potong dengan pola menonton televisi

\begin{tabular}{llc}
\hline \multirow{2}{*}{$\begin{array}{l}\text { Motif Menonton } \\
\text { Televisi }\end{array}$} & \multicolumn{2}{c}{$\begin{array}{c}\text { Pola Menonton } \\
\text { Televisi }\left(r_{\mathrm{s}}\right)\end{array}$} \\
\cline { 2 - 3 } & Frekuensi & Durasi \\
\hline Motif Informasi & 0.089 & -0.056 \\
Motif Hiburan & $0.413 * *$ & $0.424 * *$ \\
\hline Keterangan: $r_{\mathrm{s}}=$ koefisien rank Spearman \\
$* *$ berhubungan sangat nyata pada $\mathrm{p}<0.01$
\end{tabular}

Hubungan antara motif informasi dengan frekuensi dan durasi menonton televisi tidak memiliki hubungan. Ini dibuktikan dengan nilai korelasi 0.089 dan -0.056 dimana nilai $p$-value $>0.05$, artinya motif informasi tidak menimbulkan perbedaan terhadap frekuensi dan durasi menonton televisi. Berbeda antara motif hiburan memiliki hubungan nyata dengan pola menonton peternak sapi potong, ini dibuktikan dengan nilai korelasi 0.413 dan 0.424 dimana nilai $p$-value $\leq 0.01$, artinya semakin tinggi dorongan memperoleh kebutuhan hiburan akan semakin tinggi frekuensi dan durasi menontonnya.

Persamaan dengan motif audiens yang berada di perkotaan dalam menggunakan televisi sebagai hiburan, peternak Desa Ngantru juga menggunakan televisi sebagai sarana melepaskan kejenuhan, mengistirahatkan fisik dan fikiran serta melupakan persoalan. Peranan lainnya dari media televisi adalah memberi 
hiburan. Kehadiran televisi bisa dijadikan sebagai media untuk melepaskan diri dari hal-hal yang menjenuhkan, perasaan tertekan, dan mengistirahatkan tubuh dan pikiran.

\section{Hubungan Pola Menonton TV dengan Pemenuhan Kebutuhan Peternak}

Secara umum, pola menonton TV peternak berhubungan dengan pemenuhan menonton. Semakin tinggi dan lamanya kegiatan mereka menonton acara televisi, maka kecenderungan kepuasaannya pun meningkat.

Tabel 8 Nilai hubungan pola menonton televisi dengan pemenuhan kebutuhan peternak sapi potong

\begin{tabular}{lcc}
\hline $\begin{array}{l}\text { Pola } \\
\text { menonton } \\
\text { televisi }\end{array}$ & \multicolumn{2}{c}{ Pemenuhan Kebutuhan $\left(r_{\mathrm{s}}\right)$} \\
\cline { 2 - 3 } Frekuensi & 0.097 & Hiburan \\
Durasi & -0.060 & $0.367 * *$ \\
\hline $\begin{array}{l}\text { Keterangan: } r_{\mathrm{s}}=\text { koefisien rank } \text { Spearman } \\
\text { *berhubungan nyata pada } \mathrm{p}<0.05 \\
\text { **berhubungan sangat nyata pada } \mathrm{p}<0.01\end{array}$
\end{tabular}

Tabel 8 menggambarkan nilai hasil uji korelasi rank Spearman untuk melihat kekuatan dan nilai hubungan antar peubah terdapat hubungan antara frekuensi dan durasi menonton televisi dengan pemenuhan kebutuhan hiburan. Pada Tabel 8 menunjukkan nilai korelasi 0.367 dan 0.292 dimana nilai $p$-value $\leq 0.05$, artinya semakin tinggi dorongan memperoleh kebutuhan hiburan akan semakin tinggi frekuensi dan durasi menontonnya sehingga memenuhi kebutuhan hiburan bagi peternak sapi potong. Hampir sama fisik dan pikiran serta melupakan persoalan sehari-hari.

Hubungan antara pemenuhan kebutuhan informasi dengan frekuensi dan durasi menonton televisi tidak memiliki hubungan. Ini dibuktikan dengan nilai korelasi 0.097 dan -0.060 dimana nilai pvalue $>0.05$, artinya pola menonton tidak berkorelasi dengan pemenuhan kebutuhan informasi peternak. Kebutuhan informasi yang dibutuhkan oleh peternak tidak bisa sejalan dengan harapan-harapan atau keinginan peternak dalam menonton televisi.

\section{Hubungan Pemenuhan Kebutuhan Informasi dengan Peningkatan Keterampilan Peternak}

Tabel 9 menunjukkan hasil uji korelasi rank Spearman antara pemenuhan kebutuhan informasi yang didapat peternak dari menonton televisi dengan peningkatan keterampilan peternak sapi potong.

Data hasil uji statistik menunjukkan jika tidak terdapat hubungan antara keterampilan peternak dengan pemenuhan kebutuhan informasi peternak sapi. Tidak adanya hubungan antara keterampilan peternak dengan pemenuhan kebutuhan informasi peternak sapi potong disebabkan karena pemenuhan kebutuhan informasi yang didapat oleh peternak dari televisi tidak berkorelasi signifikan pada keterampilan peternak sapi potong dalam pemilihan bibit, perkandangan, pakan, kesehatan, perkawinan, dan pemasaran.

Keterampilan peternak dalam pengetahuan bibit sapi sudah didapat sejak peternak kecil. Keterampilan ini didapat dari pengalaman orang tua peternak yang

\begin{tabular}{lcccccc}
\hline Pemenuhan & \multicolumn{6}{c}{ Keterampilan Beternak Sapi potong } \\
Kebutuhan & Bibit & Kandang & Pakan & Kesehatan & Perkawinan & Pemasaran \\
\hline Informasi & -0.117 & 0.056 & -0.039 & -0.014 & 0.037 & -0.009 \\
Hiburan & & & & & & \\
\hline
\end{tabular}

dengan motif audiens yang berada di dulunya juga beternak sapi potong.

perkotaan dalam menggunakan televisi sebagai hiburan, peternak Desa Ngantru juga menggunakan televisi sebagai sarana melepaskan kejenuhan, mengistirahatkan 
Tabel 9 Nilai hubungan pemenuhan kebutuhan informasi dengan peningkatan keterampilan

Keterampilan peternak mengenai perkandangan sangat lemah, terutama pada letak kandang sapi. Kandang sapi pada peternak di Desa Ngantru sangat memperihatinkan, dimana sebagian besar peternak membuat kandang sapi bersatu dalam satu tempat tinggal mereka.

Keterampilan peternak dalam pakan sapi sudah didapat sejak dulu Keterampilan ini didapat dari pengalaman orang tua peternak sapi potong yang dulunya juga beternak sapi. Tidak adanya hubungan dengan pemenuhan kebutuhan informasi dikarenakan pengalaman dan diskusi antar peternak sapi potong membuat keterampilan peternak dalam penanaman pakan selain rumput yang tumbuh sendiri mengalami kemudahan.

Penanganan kesehatan sapi di Desa Ngantru ini masih tradisional, jika dilihat dalam pengobatan ternak yang mengalami sapi masih menggunakan bahan-bahan alami yang diracik oleh peternak sesuai dengan penyakit yang diderita oleh ternak. Pendektesi penyakit pun sangat tradisional, peternak melihat penyakit yang diderita oleh peternak dengan mata telanjang dan membutuhkan waktu beberapa hari.

Keterampilan peternak dalam perkawinan ternak sapi tidak memiliki hubungan dengan kebutuhan informasi peternak. Keterampilan ini didapat dari petugas kesehatan yang ada di Desa Ngantru, untuk menganjurkan perkawinan secara inseminasi buatan. Pengalaman perkawinan beternak secara tradisional pun masih dilakukan oleh peternak di Desa Ngantru, karenanya informasi yang didapat

Keterampilan peternak mengenai perkandangan sangat lemah, terutama pada letak kandang sapi. Kandang sapi pada peternak di Desa Ngantru sangat memperihatinkan, dimana sebagian besar peternak membuat kandang sapi bersatu dalam satu tempat tinggal mereka.

Keterampilan peternak dalam pakan sapi sudah didapat sejak dulu Keterampilan ini didapat dari pengalaman orang tua peternak sapi potong yang dulunya juga beternak sapi. Tidak adanya hubungan dengan pemenuhan kebutuhan informasi dikarenakan pengalaman dan diskusi antar peternak sapi potong membuat keterampilan peternak dalam penanaman pakan selain rumput yang tumbuh sendiri mengalami kemudahan.

Penanganan kesehatan sapi di Desa Ngantru ini masih tradisional, jika dilihat dalam pengobatan ternak yang mengalami sapi masih menggunakan bahan-bahan alami yang diracik oleh peternak sesuai dengan penyakit yang diderita oleh ternak. Pendektesi penyakit pun sangat tradisional, peternak melihat penyakit yang diderita oleh ternak mereka dengan mata telanjang dan membutuhkan waktu beberapa hari.

Keterampilan peternak dalam perkawinan ternak sapi tidak memiliki hubungan dengan kebutuhan informasi peternak. Keterampilan ini didapat dari petugas kesehatan yang ada di Desa Ngantru, untuk menganjurkan perkawinan secara inseminasi buatan (IB). Pengalaman perkawinan beternak secara tradisional pun masih dilakukan oleh peternak di Desa Ngantru, karenanya informasi yang didapat dari televisi tidak memberi kebutuhan yang diperlukan oleh peternak.

Keterampilan peternak dalam pemasaran tidak memiliki hubungan dengan pemenuhan kebutuhan informasi dikarenakan peternak menjual langsung ternaknya melalui tengkulak tidak langsung ke pasar, ini dikarenakan jarak yang ditempuh sangat sulit dan jauh. Harga yang ditawarkan tengkulak biasanya harga yang terlalu di bawah dari harga pasaran sehingga peternak tidak sedikt yang menerima keuntungan yang sedikit apabila dibandingkan menjual ternaknya ke pasar langsung.

\section{SIMPULAN DAN SARAN}




\section{Simpulan}

Dari hasil penelitian dapat disimpulkan sebagai berikut:

1. Peternak memiliki motif informasi dan motif hiburan yang cukup tinggi untuk menonton televisi.

2. Frekuensi peternak dalam menonton televisi tergolong tinggi, sedangkan untuk durasi peternak tergolong rendah.

3. Hubungan karakteristik hanya satu yang berhubungan nyata dengan peubah pola menonton, yaitu tingkat kepemilikan ternak dengan durasi menonton peternak. Hubungan motif hiburan berhubungan dengan pola menonton yaitu frekuensi dan durasi menonton. Pola peternak sapi potong menonton televisi berhubunan nyata dengan pemenuhan kebutuhan pada aspek hiburan.

4. Kebutuhan informasi peternak tidak berkorelasi nyata dengan peningkatan keterampilan mereka dalam beternak sapi potong.

1. Pemerintah daerah Kabupaten Bojonegoro hendaknya dapat memberikan informasi berkaitan dengan peternakan sapi potong berupa informasi budidaya dan pemasaran melalui media local, dan mengemasnya dengan budaya setempat.

2. Penyuluh lebih dapat berkomunikasi lebih baik lagi dalam memberikan informasi peternakan, menggunakan media seperti video dapat memberikan peternak pengetahuan dan keterampilan yang tepat karena bisa ditonton berulang kali.

\section{DAFTAR PUSTAKA}

Yusuf. 2010. Kompetensi peternak dalam pengelolaan usaha sapi potong di Kabupaten Konawe Provinsi Sulawesi Tenggara. [tesis]. Bogor
Batoa H. 2007. Faktor-faktor yang berhubungan dengan kompetensi petani rumput laut di Kabupaten Konawe Provinsi Sulawesi Tenggara. [tesis]. Bogor (ID): Institut Pertanian Bogor

[BPS] Badan Pusat Statistik. 2014. Produksi daging ternak menurut provinsi dan jenis ternak tahun 2007-2013. [Internet]. [diunduh 10 September http://www.bps.go.id

Jahi A. 1998. Komunikasi massa dan pembangunan pedesaan di negaranegara dunia ketiga. Jakarta (ID): Gramedia.

Rakhmat J. 2007. Psikologi Komunikasi. Bandung (ID): Remaja Rosdakarya.

Rosalita. 2014. Hubungan karakteristik masyarakat Desa Cibanteng dengan perilaku menonton dan literasi media acara televisi Prime Time. [skripsi]. Bogor (ID): IPB.

Saleh A. 2006. Tingkat penggunaan media massa dan peran komunikasi anggota kelompok peternak dalam jaring komunikasi penyuluhan sapi potong. Media Peternakan [Internet]. [diunduh 10 September 2014]. 29 (2). 107-120. http://jesl.journal.ipb.ac.id/index.p $\underline{\mathrm{hp} / \text { mediapeternakan }}$

Undang-Undang No.32 Tahun 2002 tentang Penyiaran. Jakarta (ID).

Wibowo S A, Haryadi F T. 2006. Faktor karakteristik peternak yang mempengaruhi sikap terhadap program kredit sapi potong di kelompok peternak Andiniharjo Kabupaten Sleman Yogyakarta. Media Peternakan [Internet]. [diunduh 18 September 2016].29 (3):176-186. http://jesl.journal.ipb. ac.id/index.php/mediapeternakan.

(ID): Pascasarjana Institut Pertanian Bogor. 
Jurnal Komunikasi Pembangunan

ISSN 1693-3699

Juli 2016 Vol 14, No 2 